\title{
A systematic mapping review of Randomized Controlled Trials (RCTs) in care homes
}

\author{
Adam L Gordon ${ }^{1 *}$, Phillipa A Logan ${ }^{1}$, Rob G Jones ${ }^{2}$, Calum Forrester-Paton ${ }^{3}$, Jonathan P Mamo ${ }^{4}$, \\ John RF Gladman ${ }^{1}$ and Medical Crises in Older People Study Group
}

\begin{abstract}
Background: A thorough understanding of the literature generated from research in care homes is required to support evidence-based commissioning and delivery of healthcare. So far this research has not been compiled or described. We set out to describe the extent of the evidence base derived from randomized controlled trials conducted in care homes.

Methods: A systematic mapping review was conducted of the randomized controlled trials (RCTs) conducted in care homes. Medline was searched for "Nursing Home", "Residential Facilities" and "Homes for the Aged"; CINAHL for "nursing homes", "residential facilities" and "skilled nursing facilities"; AMED for "Nursing homes", "Long term care", "Residential facilities" and "Randomized controlled trial"; and BNI for "Nursing Homes", "Residential Care" and "Long-term care". Articles were classified against a keywording strategy describing: year and country of publication; randomization, stratification and blinding methodology; target of intervention; intervention and control treatments; number of subjects and/or clusters; outcome measures; and results.
\end{abstract}

Results: 3226 abstracts were identified and 291 articles reviewed in full. Most were recent (median age 6 years) and from the United States. A wide range of targets and interventions were identified. Studies were mostly functional (44 behaviour, 20 prescribing and 20 malnutrition studies) rather than disease-based. Over a quarter focussed on mental health.

Conclusions: This study is the first to collate data from all RCTs conducted in care homes and represents an important resource for those providing and commissioning healthcare for this sector. The evidence-base is rapidly developing. Several areas - influenza, falls, mobility, fractures, osteoporosis - are appropriate for systematic review. For other topics, researchers need to focus on outcome measures that can be compared and collated.

\section{Background}

Care homes provide accommodation, together with nursing or personal care, for persons who are or have been ill, who have or have had a mental disorder, who are disabled or infirm, or are or have been dependent on alcohol or drugs [1]. In the UK, $91 \%$ of residents are over 70 years of age, $76 \%$ require assistance with mobility or are immobile and $78 \%$ have at least one form of mental impairment [2].

In some countries, such as the Netherlands and USA, health care professionals are based within, or employed by, care homes [3-5]. In others, such as the UK or

\footnotetext{
* Correspondence: adam.gordon@nottingham.ac.uk

'Division of Rehabilitation and Ageing, University of Nottingham, Nottingham, UK

Full list of author information is available at the end of the article
}

Ireland, the health care provision for care homes is provided by generic primary care services. The provision of health care to this sector is a matter of concern, debate and innovation [4-8].

Quest for Quality, a document by the British Geriatrics Society [6], stated that health care for care homes in the UK was characterised by "unmet need, unacceptable variation and often poor quality of care". To improve matters, the report recommended the development of a more structured and evidence-based approach to commissioning. To inform this process, we set out to describe the extent of the evidence-base for the effectiveness of interventions specific to care home residents. We chose a systematic mapping review because these are specifically designed to describe the extent of research in a field $[7,8]$. We chose to review only

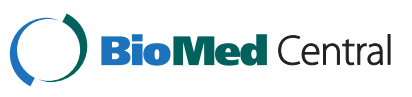


randomised controlled trials (RCT) so that the findings would represent the highest tier of medical evidence for therapeutic interventions [9].

\section{Methods}

Medline (1950-Jun 2009) was searched for "Nursing Home", "Residential Facilities" and "Homes for the Aged", combined using the "OR" command. Results were limited for English language and RCTs. CINAHL with full text (1978-June 2009) was searched for "nursing homes", "residential facilities", "skilled nursing facilities", with results limited to RCTs. The Allied and Complementary Medicine Database (AMED) (1985-June 2009) was searched for "Nursing homes", "Long term care" and "Residential facilities" combined using the "OR" command and "Randomized controlled trial" using the "AND" command. The British Nursing Index and Archive (BNI) (1985-June 2009) was searched for "Nursing Homes", "Residential Care" and "Long-term care". Abstracts were reviewed by a single researcher and articles included if they described interventions evaluated by RCT in residential, nursing or care homes.

A keywording strategy [8] was developed by three researchers using an iterative approach and a random sample of 20 articles, which were reviewed repetitively with key descriptors recorded. The researchers met after each iteration and the process concluded when two subsequent reviews identified no new descriptors. The resulting framework described: year of publication, country of publication, individual or cluster randomization, stratified or non-stratified randomization, method of stratification, blinding strategy (patient/investigators/ both/neither), target of intervention, intervention treatment, control treatment, number of subjects (total/intervention/control), number of clusters (total/intervention/ control), outcome measures and results. The remaining articles were then divided amongst six reviewers who classified them according to the keywording strategy. As a final measure, all articles were reviewed by the lead researcher with disagreements resolved by consensus.

\section{Results}

The abstracts of the 3226 unique citations identified from the search were examined, 331 of which described RCTs in care homes. Forty of these were excluded at full review leaving 291 articles in this review. A PRISMA flow diagram is shown in Figure 1.

The majority of studies (145) were conducted in the USA, followed by the UK (24) and the Netherlands (23): 163 articles came from the Americas, 87 articles from Europe, 23 from Asia and 16 from Australasia.

Figure 2, showing the publication rate by year, demonstrates a steady increase in the number of publications over the last two decades. The median age of the publications was 6 years.

Key methodological attributes of the studies are outlined in Table 1.

36 primary targets for interventions were identified, as summarised in Table 2.

For interventions targeting resident behaviour, most pharmacological studies evaluated risperidone [22-26] or olanzapine $[18,19]$. Two studies evaluated interventions aimed at withdrawal of antipsychotic medications $[27,28]$. Studies listed under occupational therapy, aids and appliances targeting behaviour were heterogeneous and included Activities of Daily Living (ADL)-targeted interventions [29,30], re-orientation [31], pet therapy [32] and music therapy [33-35]. Physical therapy studies evaluated either light therapy [37-39] or exercise therapy [36]. Staff education interventions focussed either around communication [41-43] or goal-setting [40].

Seven studies targeting prescribing of medications looked at incorporating pharmacist review, with or without physician involvement, into clinical pathways on or after admission to care home [55-57,61-63,65]. Other, more targeted interventions considered protocols for the withdrawal of hypnotics [54], neuroleptics [59,66], antidepressants [58] and anti-Parkinsonian [67] drugs. Two studies evaluated the effects of specific antibiotic protocols on prescribing $[60,64]$. Six studies evaluated the impact of staff education on prescribing, three considered teaching on psychopharmacology $[69,70,73]$, one on generic prescribing issues [72], one on antibiotics [68] and one on pain management [71].

The majority of studies targeting nutrition evaluated nutritional supplementation using vitamin, mineral, and/ or protein-energy supplementation [78,79,81-89,93]. Three studies, all from the same authors, evaluated the effect of megestrol acetate on nutritional biomarkers [90-92]. Other studies evaluated the effect of flavour enhancers [77], dietary restriction [80], family-style dining arrangements $[75,129]$ and the provision of feeding assistance [76].

Studies targeting influenza in residents predominantly compared doses or types of vaccine [94-96,101,102,104106]. Three studies compared influenza vaccination with placebo $[97,99,100]$ and two with usual care $[98,103]$. Six evaluated neuraminidase inhibitors [107-112].

Studies targeting quality of life were heterogeneous. Under this heading, studies evaluating psychological or behavioural interventions evaluated group or individual therapies to build self-esteem [113,114] or reminiscence therapy $[115,116]$. Occupational therapy-oriented studies to improve quality of life evaluated spectacle correction of eyesight, engagement in teaching and pets [117-119]. Physical therapy studies to improve quality of life evaluated tai chi, back rubs and functional 


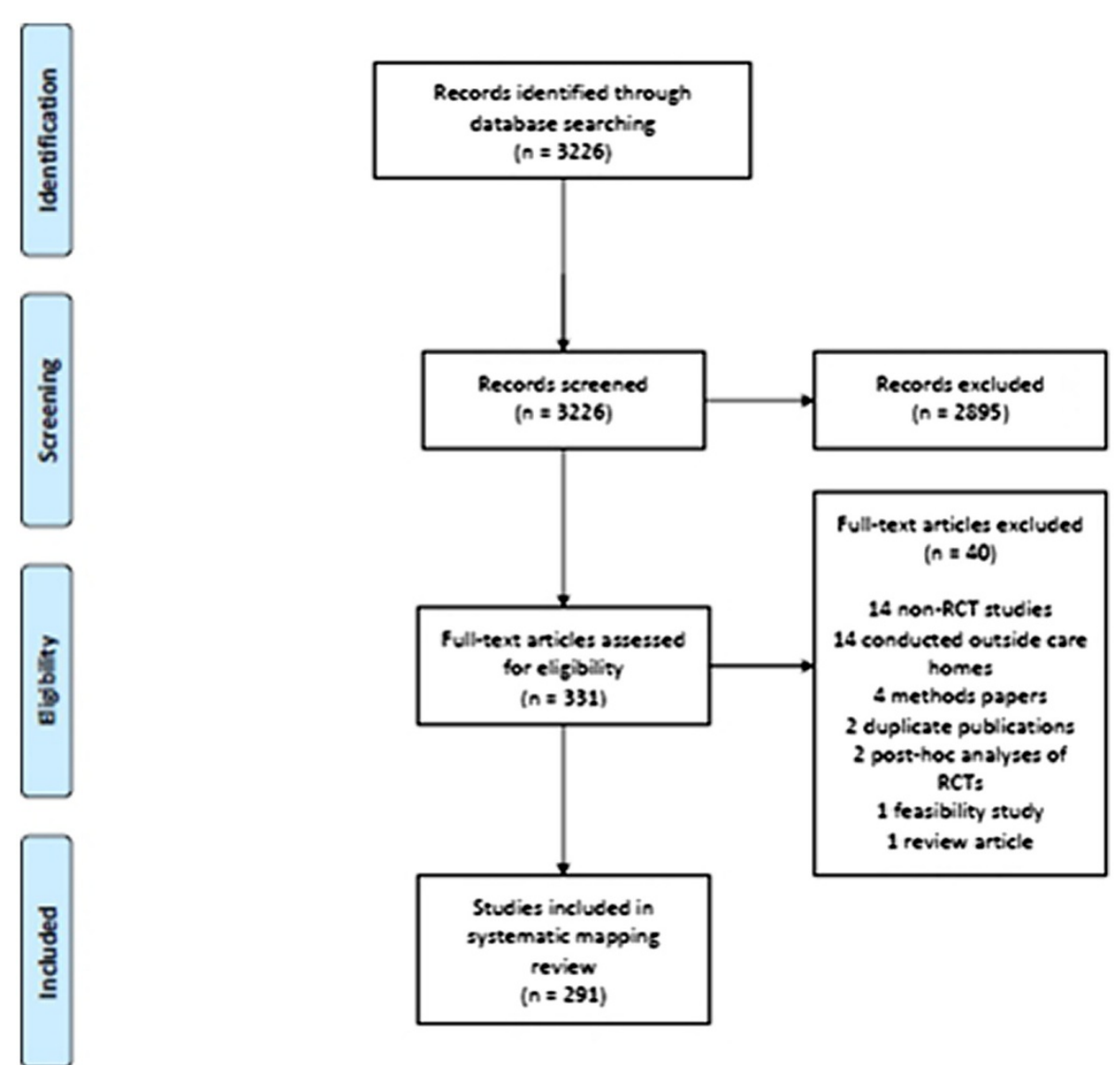

Figure 1 PRISMA flow diagram.

incidental training [120-122]. Staff training interventions to improve quality of life evaluated teaching about endof-life care, dementia management and conflict resolution [123-125].
Studies targeting depression evaluated exercise therapy [132-134,136,137], light therapy [131] and yoga [138]. There were four studies of antidepressants [140-143], one of reminiscence [144] and one of self worth therapy [145].

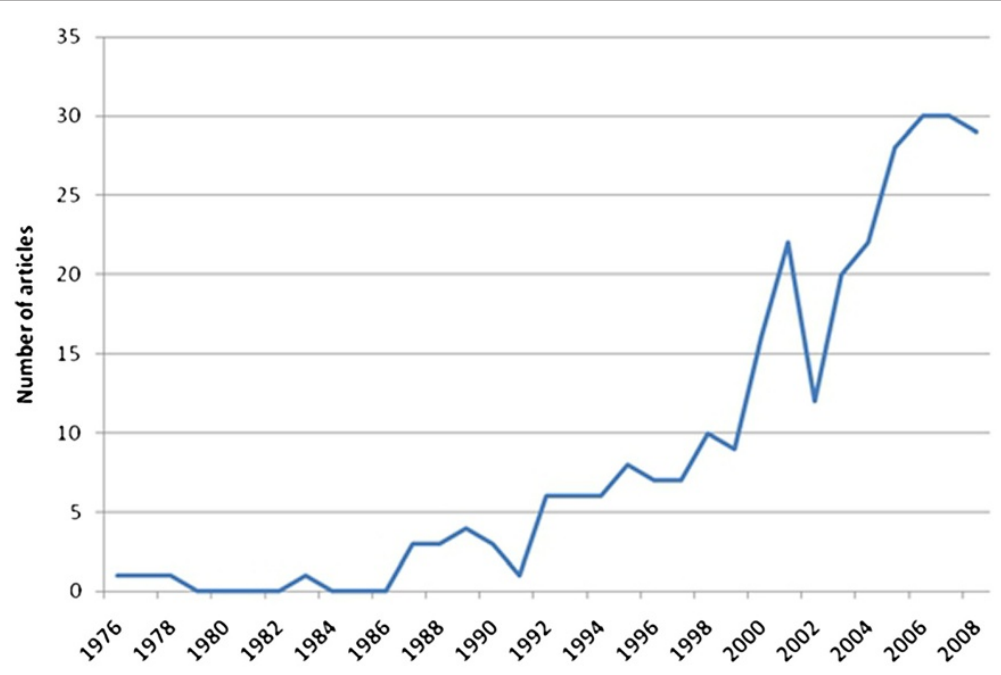

Figure 2 Number of articles published by year. 
Table 1 Methodological attributes of studies

\begin{tabular}{|c|c|c|c|c|}
\hline & \multicolumn{4}{|l|}{ Blinding } \\
\hline & $\begin{array}{l}\text { Double } \\
\text { blind }\end{array}$ & $\begin{array}{l}\text { Participant } \\
\text { blinded } \\
\text { only }\end{array}$ & $\begin{array}{l}\text { Outcome } \\
\text { assessor } \\
\text { blinded } \\
\text { only }\end{array}$ & Unblinded \\
\hline Cluster & 6 & 0 & 18 & 44 \\
\hline Cluster Crossover & 1 & 0 & 5 & 3 \\
\hline Individual Patient & 70 & 5 & 42 & 74 \\
\hline $\begin{array}{l}\text { Individual Patient } \\
\text { Crossover }\end{array}$ & 8 & 2 & 7 & 7 \\
\hline
\end{tabular}

Interventions targeting mobility were much more homogenous. Ten physical therapy studies all evaluated forms of exercise therapy [148-157] while two of the three occupational therapy interventions evaluated multi-faceted mobility interventions [158,159]. The final study evaluated visual feedback balance training [160].

Oral health studies predominantly evaluated the role of mouthwashes, toothpastes and other oral preparations in dental hygiene [161,162,165,166,169] but also evaluated toothbrushing technologies and techniques $[164,170,171]$, oral healthcare education $[168,172]$, restorative dentistry [163] and denture care [167]. One study evaluated subantimicrobial doses of an antibiotic as a treatment for chronic periodontitis [173].

The majority of studies that evaluated falls prevention interventions focussed on multifaceted programmes [174179]. Two studies evaluated the role of vitamin D supplementation [180,181] and two evaluated exercise therapy $[182,183]$. One evaluated the role of care home governance in falls documentation [184] and one evaluated the impact of staff education on falls rates [185].

Studies targeting quality of care focussed predominantly on care home administration: four examined quality assurance programmes [189-192], two the implementation of advanced care planning or advanced directives [186,187], one communication with families [188] and one resident relocation [193]. The remaining studies evaluated the impact of staff education on bathing [194], communication [195] and death and dying [196].

Of the less frequently studied areas, large cohorts were seen in studies targeting fractures and osteoporosis. These areas were also notable for the similarity of the interventions studied and outcome measures recorded: all eight fracture studies evaluated hip protectors [225232] and four [248-251] out of seven osteoporosis studies evaluated calcium and vitamin D therapy, with or without bisphosphonates, whilst a further study evaluated alendronate as a standalone therapy [247].

Ten studies evaluated case management in the care home setting. The effect of psychiatric case management was evaluated in six studies, two on behavioural disturbance $[49,51]$, two on depression $[51,146]$ and two on quality of life $[128,197]$. Four studies evaluated broader assessment and management taking account of somatic, psychological and environmental issues, which might be termed comprehensive geriatric assessment [48,254,255,287]. One study evaluated protocol-driven disease management for COPD by care home nurses [292].

\section{Conclusions}

These findings provide a unique resource for those providing health care to the care home sector, collating for the first time the range of interventions and outcomes that have been tested using RCTs specifically in care homes. There have been a considerable number of RCTs of interventions specifically in care homes (292 between 1974 and 2009). These studies are relatively recent, since half of them were published in the last 6 years. They evaluated a diverse range of interventions such as light therapy, staff training and oral hygiene and an equally diverse range of targets such as reducing falls, increasing weight or improving mood. The studies were mostly functional (44 behaviour studies, 20 prescribing studies, 20 malnutrition studies) rather than disease based (1 study each for UTI and COPD). Over a quarter of papers focussed on mental health or behaviour. Despite our use of systematic searching, we found no previously published studies that had collated this literature.

A limitation of this review is the geographical distribution of papers, with the majority of studies arising from the USA and relatively few from non-English speaking nations, thus reducing the generalisability of the findings worldwide. Our decision to select only RCTs means that we have not collated the entire evidence base for interventions in care homes and are likely to have missed several important studies as a consequence. Such studies would include those focussing on policy, facility organizational characteristics and the ways in which care homes interact with other care services, including the health service - these have been recognised to be important drivers of care quality but have been studied by means other than RCT [6].

It is possible that staff trained in the care home setting - as some doctors are in the Netherlands or USA - are aware of many of these studies but it is less likely that those who provide health care to care homes as part of generic primary care will be familiar with them. The recent growth in the number of papers means that even health care professionals with an interest in the area will be out of date if they have not recently consulted the literature. The wide-ranging nature of the studies identified will have relevance to commissioners, and health care professions including general practitioners, geriatricians, psychiatrists, nurses, occupational, physio- and speech and language therapists, dieticians, dentists, pharmacists and social workers - as well as care home 
Table 2 Targets of interventions

\section{Target and type of interventions}

Behaviour

Pharmacological [10-28]

Occupational therapy, aids and appliances [29-35]

Physical therapy [36-39]

Staff education [40-43]

Psychological or behavioural Therapy [44-47]

Case management [48-51]

Nursing, not classified elsewhere [52]

Aromatherapy [53]

Prescribing

Pharmacological [54-67]

Staff education [68-73]

Malnutrition

Nutritional [74-89]

Pharmacological [90-93]

Influenza

Vaccination [94-106]

Pharmacological [107-112]

Quality of Life

Psychological or behavioural therapy [113-116]

Occupational therapy, aids and appliances [117-119]

Physical therapy [120-122]

Staff and family education [123-125]

Care home administration [126,127]

Case management [128]

Nutritional [129]

Nursing, not classified elsewhere [130]

Depression

Physical therapy [131-139]

Pharmacological [140-143]

Psychological or behavioural therapy $[144,145]$

Case management [146]

Occupational therapy, aids and appliances [147]

Mobility

Physical therapy [148-157]

Occupational therapy, aids and appliances [158-160]

Oral Health

Dental and oral health interventions [161-172]

Pharmacological [173]

Falls

Occupational therapy, aids and appliances [174-179]

Pharmacological [180,181]

Physical therapy $[182,183]$

Care home administration [184]
Number of studies

Number of participants

44

19

4482

2521

7

4

4 
Table 2 Targets of interventions (Continued)

\begin{tabular}{|c|c|c|}
\hline Staff education [185] & 1 & 379 \\
\hline Quality of Care & 12 & 11947 \\
\hline Care home administration [186-193] & 8 & 10417 \\
\hline Staff education [194-196] & 3 & 1338 \\
\hline Case management [197] & 1 & 192 \\
\hline Urinary incontinence & 12 & 896 \\
\hline Occupational therapy, aids and appliances [198-203] & 6 & 410 \\
\hline Pharmacological [204-207] & 4 & 216 \\
\hline Physical therapy [208] & 1 & 190 \\
\hline Nursing, not classified elsewhere [209] & 1 & 80 \\
\hline Cognitive performance & 7 & 536 \\
\hline Physical therapy [210-212] & 3 & 125 \\
\hline Pharmacological $[213,214]$ & 2 & 371 \\
\hline Psychological or behavioural therapy $[215,216]$ & 2 & 40 \\
\hline Sleep & 8 & 488 \\
\hline Physical therapy [217-223] & 7 & 474 \\
\hline Pharmacological [224] & 1 & 14 \\
\hline Fractures & 8 & 10221 \\
\hline Occupational therapy, aids \& appliances [225-232] & 8 & 10221 \\
\hline Immunity & 8 & 1304 \\
\hline Pharmacological [233-237] & 6 & 890 \\
\hline Nutrititional [238] & 1 & 257 \\
\hline Physical therapy [239] & 1 & 157 \\
\hline Decubitus Ulcers & 7 & 658 \\
\hline Occupational therapy, aids and appliances $[240,241]$ & 2 & 116 \\
\hline Pharmacological $[242,243]$ & 2 & 145 \\
\hline Physical therapy $[244,245]$ & 2 & 162 \\
\hline Nursing, not classified elsewhere [246] & 1 & 235 \\
\hline Osteoporosis & 7 & 14096 \\
\hline Pharmacological [247-251] & 5 & 7853 \\
\hline Care home administration [252] & 1 & 5637 \\
\hline Staff education [253] & 1 & 606 \\
\hline Pain & 7 & 1038 \\
\hline Case management $[254,255]$ & 2 & 232 \\
\hline Physical therapy $[256,257]$ & 2 & 73 \\
\hline Psychological or behavioural therapy [258] & 1 & 21 \\
\hline Pharmacological [259] & 1 & 39 \\
\hline Staff education [260] & 1 & 673 \\
\hline Physical Function & 6 & 726 \\
\hline Occupational therapy, aids and appliances [261-264] & 4 & 368 \\
\hline Care home administration [265] & 1 & 164 \\
\hline Physical therapy [266] & 1 & 194 \\
\hline Constipation & 5 & 494 \\
\hline Nutritional [267-270] & 4 & 337 \\
\hline Physical therapy [271] & 1 & 157 \\
\hline
\end{tabular}


Table 2 Targets of interventions (Continued)

\begin{tabular}{|c|c|c|}
\hline Respiratory infection & 5 & 1724 \\
\hline Pharmacological [272-275] & 4 & 1063 \\
\hline Care home administration [276] & 1 & 661 \\
\hline Physical Restraint Use & 3 & 758 \\
\hline Staff education [277-279] & 3 & 758 \\
\hline Skin Health & 3 & 205 \\
\hline Nursing, not classified elsewhere $[280,281]$ & 2 & 61 \\
\hline Physical therapy [282] & 1 & 144 \\
\hline Vitamin D deficiency & 3 & 217 \\
\hline Pharmacological $[283,284]$ & 2 & 172 \\
\hline Physical therapy [285] & 1 & 45 \\
\hline General health & 3 & 585 \\
\hline Care home administration [286] & 1 & 464 \\
\hline Case management [287] & 1 & 69 \\
\hline Pharmacological [288] & 1 & 52 \\
\hline Swallowing & 2 & 78 \\
\hline Pharmacological [289] & 1 & 63 \\
\hline Physical therapy [290] & 1 & 15 \\
\hline Compliance with OT [291] & 1 & 30 \\
\hline COPD [292] & 1 & 89 \\
\hline Cough Reflex Sensitivity [293] & 1 & 59 \\
\hline Dehydration [294] & 1 & 63 \\
\hline Dementia [295] & 1 & 426 \\
\hline Faecal Incontinence [296] & 1 & 178 \\
\hline Hypertension [297] & 1 & 30 \\
\hline Interpersonal skills [298] & 1 & 27 \\
\hline Microbial colonisation [299] & 1 & 283 \\
\hline UTI [300] & 1 & 50 \\
\hline
\end{tabular}

staff. From a research perspective, there were few targets where multiple studies evaluated similar interventions against a common outcome measure. The obvious exceptions were influenza, falls, mobility, fractures and osteoporosis and these areas are suitable for systematic reviewing. There was great diversity of interventions and targets, such that there were few papers using the same intervention and the same target. Thus, despite the large numbers of papers found, much work remains to be done to develop a robust evidence-base for each intervention and each target. Although a detailed methodological critique is beyond the scope of a systematic mapping review, the fact that the majority of studies were unblinded and did not employ cluster randomization means that many will have been methodologically flawed.

In summary, these findings represent an important resource for commissioners, clinicians and researchers involved with care homes. At the very least, the diversity of interventions and outcomes illustrated should challenge nihilism towards this health care sector and encourage further innovation.

\section{Competing interests}

The authors have no competing interests to declare.

\section{Authors' contributions}

ALG was lead researcher and also lead author. JRFG and PAL contributed to the development of the keywording strategy. All authors participated in the literature review and contributed to drafting the final manuscript. All authors read and approved the final manuscript.

\section{Acknowledgements}

This article presents independent research commissioned by the National Institute for Health Research (NIHR) under its Programme Grants for Applied Research funding scheme (RP-PG-0407-10147). The views expressed in this publication are those of the author(s) and not necessarily those of the NHS, the NIHR or the Department of Health.

The authors would also like to acknowledge the support of the British Geriatrics Society, who provided an SpR start-up grant in support of ALG at the outset of this project. 
The Medical Crises in Older People study group also includes: Isabella Robbins, Jane Dyas, Justine Schneider, Sarah Goldberg, Rowan Harwood, Kathy Whittamore, Sarah Lewis, Simon Conroy, Anthony Avery, Fiona Jurgens, Judi Edmans, Lucy Bradshaw, Helen Boardman, Rachel Elliot, Matt Franklin and Davina Porock.

\section{Author details}

${ }^{1}$ Division of Rehabilitation and Ageing, University of Nottingham, Nottingham, UK. ²Department of Psychiatry, University of Nottingham, Nottingham, UK. ${ }^{3}$ Department of Health Care of Older People, Nottingham University Hospitals NHS Trust, Nottingham, UK. ${ }^{4}$ Department of Medicine, Peterborough City Hospital, Peterborough, UK.

Received: 16 November 2011 Accepted: 25 June 2012

Published: 25 June 2012

\section{References}

1. Great Britain Department of Health: Care Standards Act 2000. London: Stationery Office; 2001

2. Bowman C, Whistler J, Ellerby M: A national census of care home residents. Age Ageing 2004, 33(6):561-566.

3. Helton MR, Cohen LW, Zimmerman S, van der Steen JT: The Importance of Physician Presence in Nursing Homes for Residents with Dementia and Pneumonia. J Am Med Dir Assoc 2011, 12(1):68-73.

4. Katz PR, Karuza J, Intrator O, Mor V: Nursing Home Physician Specialists: A Response to the Workforce Crisis in Long-Term Care. Ann Intern Med 2009, 150(6):411-413.

5. Conroy S, Van Der Cammen $T$, Schols J, Van Balen R, Peteroff $P$, Luxton T: Medical services for older people in nursing homes Comparing services in England and The Netherlands. J Nutr Health Aging 2009, 13(6):559-563.

6. British Geriatrics Society: Quest for Quality: British Geriatrics Society Joint Working Party Inquiry into the Quality of Healthcare Support for Older People in Care Homes:A Call for Leadership, Partnership and Quality Improvement. London: British Geriatrics Society; 2011.

7. Grant MJ, Booth A: A typology of reviews: an analysis of 14 review types and associated methodologies. Health Info Libr J 2009, 26(2):91-108.

8. Evidence for Policy and Practice Information and Co-ordinating Centre: EPPI Educational Keywording Strategy. http://eppi.ioe.ac.uk/EPPIWebContent/ downloads/EPPI_Keyword_strategy_0.9.7.pdf (last accessed Feb 13th, 2011).

9. GRADE working group: Grading quality of evidence and strength of recommendations. BMJ 2004, 328(7454):1490.

10. Chibnall JT, Tait RC, Harman B, Luebbert RA: Effect of Acetaminophen on Behavior, Well-Being, and Psychotropic Medication Use in Nursing Home Residents with Moderate-to-Severe Dementia. J Am Geriatr Soc 2005, 53(11):1921-1929.

11. Christensen DB, Benfield WR: Alprazolam as an Alternative to Low-Dose Haloperidol in Older, Cognitively Impaired Nursing Facility Patients. J Am Geriatr Soc 1998, 46(5):620-625.

12. Streim JE, Porsteinsson AP, Breder CD, Swanink R, Marcus R, McQuade R, Carson WH: A Randomized, Double-Blind, Placebo-Controlled Study of Aripiprazole for the Treatment of Psychosis in Nursing Home Patients with Alzheimer Disease. Am J Geriatr Psychiatry 2008 16(7):537-550.

13. Tariot PN, Erb R, Podgorski CA, Cox C, Patel S, Jakimovich L, Irvine C: Efficacy and Tolerability of Carbamazepine for Agitation and Aggression in Dementia. Am J Psychiatry 1998, 155(1):54-61.

14. Tariot PN, Cummings JL, Katz IR, Mintzer J, Perdomo CA, Schwam EM, Whalen E: A Randomized, Double-Blind, Placebo-Controlled Study of the Efficacy and Safety of Donepezil in Patients with Alzheimer's Disease in the Nursing Home Setting. J Am Geriatr Soc 2001, 49(12):1590-1599.

15. Tariot PN, Raman $R$, Jakimovich $L$, Schneider $L$, Porsteinsson A, Thomas $R$, Mintzer J, Brenner R, Schafer K, Thal L: Divalproex Sodium in Nursing Home Residents With Possible or Probable Alzheimer Disease Complicated by Agitation: A Randomized, Controlled Trial. Am J Geriatr Psychiatry 2005, 13(11):942-949.

16. Coccaro E, Kramer E, Zemishlany Z, Thorne A, Rice C, Giordani B, Duvvi K, Patel B, Torres J, Nora R: Pharmacologic treatment of noncognitive behavioral disturbances in elderly demented patients. Am J Psychiatry 1990, 147(12):1640-1645.
17. Gehrman PR, Connor DJ, Martin JL, Shochat T, Corey-Bloom J, Ancoli-Israel S: Melatonin Fails to Improve Sleep or Agitation in Double-Blind Randomized Placebo-Controlled Trial of Institutionalized Patients With Alzheimer Disease. Am J Geriatr Psychiatry 2009, 17(2):166-169.

18. Clark WS, Street JS, Feldman PD, Breier A: The effects of olanzapine in reducing the emergence of psychosis among nursing home patients with Alzheimer's disease. J Clin Psychiatry 2001, 62(1):34-40.

19. Street JS, Clark WS, Gannon KS, Cummings JL, Bymaster FP, Tamura RN, Mitan SJ, Kadam DL, Sanger TM, Feldman PD: Olanzapine Treatment of Psychotic and Behavioral Symptoms in Patients With Alzheimer Disease in Nursing Care Facilities: A Double-blind, Randomized, PlaceboControlled Trial. Arch Gen Psychiatry 2000, 57(10):968-976.

20. Peskind ER, Tsuang DW, Bonner LT, Pascualy M, Riekse RG, Snowden MB, Thomas R, Raskind MA: Propranolol for Disruptive Behaviors in Nursing Home Residents With Probable or Possible Alzheimer Disease: A Placebo-Controlled Study. Alzheimer Dis Assoc Disord 2005, 19(1):23-28.

21. Meguro K, Meguro M, Tanaka Y, Akanuma K, Yamaguchi K, Itoh M: Risperidone is effective for wandering and disturbed sleep/wake patterns in Alzheimer's disease. J Geriatr Psychiatry Neurol 2004, 17 (2):61-67.

22. Brodaty H, Ames D, Snowdon J, Woodward M, Kirwan J, Clarnette R, Lee E, Greenspan A: Risperidone for psychosis of Alzheimer's disease and mixed dementia: results of a double-blind, placebo-controlled trial. Int J Geriatr Psychiatry 2005, 20(12):1153-1157.

23. Suh G-H, Greenspan AJ, Sung-Ku Choi: Comparative efficacy of risperidone versus haloperidol on behavioural and psychological symptoms of dementia. Int J Geriatr Psychiatry 2006, 21(7):654-660.

24. Frank L, Kleinman L, Ciesla G, Rupnow MF, Brodaty H: The Effect of Risperidone on Nursing Burden Associated with Caring for Patients with Dementia. J Am Geriatr Soc 2004, 52(9):1449-1455.

25. Brodaty H, Ames D, Snowdon J, Woodward M, Kirwan J, Clarnette R, Lee E, Lyons B, Grossman F: A randomized placebo-controlled trial of risperidone for the treatment of aggression, agitation, and psychosis of dementia. J Clin Psychiatry 2003, 64(2):134-143.

26. Mintzer J, Greenspan A, Caers I, Van Hove I, Kushner S, Weiner M, Gharabawi G, Schneider LS: Risperidone in the Treatment of Psychosis of Alzheimer Disease: Results From a Prospective Clinical Trial. Am J Geriatr Psychiatry 2006, 14(3):280-291.

27. Ruths S, Straand J, Nygaard HA, Bjorvatn B, Pallesen S: Effect of Antipsychotic Withdrawal on Behavior and Sleep/Wake Activity in Nursing Home Residents with Dementia: A Randomized, PlaceboControlled, Double-Blinded Study The Bergen District Nursing Home Study. J Am Geriatr Soc 2004, 52(10):1737-1743.

28. Ruths S, Straand J, Nygaard HA: Dag Aarsland: Stopping antipsychotic drug therapy in demented nursing home patients: a randomized, placebo-controlled study-The Bergen District Nursing Home Study (BEDNURS). Int J Geriatr Psychiatry 2008, 23(9):889-895.

29. Rovner BW, Steele CD, Shmuely Y, Folstein MF: A randomized trial of dementia care in nursing homes. J Am Geriatr Soc 1996, 44(1):7-13.

30. Beck C, Vogelpohl T, Rasin J, Uriri J, O'Sullivan P, Walls R, Phillips R, Baldwin B: Effects of behavioral interventions on disruptive behavior and affect in demented nursing home residents. Nurse Res 2002, 51(4):219-228.

31. McGilton K, Rivera T, Dawson P: Can we help persons with dementia find their way in a new environment? Aging Ment Health 2003, 7(5):363-363.

32. Colombo G, Buono MD, Smania K, Raviola R, De Leo D: Pet therapy and institutionalized elderly: A study on 144 cognitively unimpaired subjects. Arch Gerontol Geriatr 2006, 42(2):207-216.

33. Holmes C, Knights A, Dean C, Hodkinson S, Hopkins V: Keep music live: music and the alleviation of apathy in dementia subjects. Int Psychogeriatr 2006, 18:623-630.

34. Svansdottir H, Snaedal J: Music therapy in moderate and severe dementia of Alzheimer's type: a case-control study. Int Psychogeriatr 2006, 18:613-621.

35. Sung $\mathrm{H}-\mathrm{C}$, Chang $\mathrm{S}-\mathrm{M}$, Lee $\mathrm{W}-\mathrm{L}$, Lee $M-S$ : The effects of group music with movement intervention on agitated behaviours of institutionalized elders with dementia in Taiwan. Complement Ther Med 2006, 14(2):113-119.

36. Rolland Y, Pillard F, Klapouszczak A, Reynish E, Thomas D, Andrieu S, Riviare $D$, Vellas B: Exercise program for nursing home residents with 
Alzheimer's disease: a 1-year randomized, controlled trial. J Am Geriatr Soc 2007, 55(2):158-165.

37. Dowling GA, Graf CL, Hubbard EM, Luxenberg JS: Light Treatment for Neuropsychiatric Behaviors in Alzheimers Disease. West J Nurs Res 2007, 29(8):961-975.

38. Lyketsos CG, Veiel LL, Baker A, Steele C: A randomized, controlled trial of bright light therapy for agitated behaviors in dementia patients residing in long-term care. Int J Geriatr Psychiatry 1999, 14(7):520-525.

39. Ancoli-Israel S, Martin J, Gehrman P, Shochat T, Corey-Bloom J, Marler M, Nolan S, Levi L: Effect of light on agitation in institutionalized patients with severe Alzheimer disease. Am J Geriatr Psychiatry 2003, 11(2):194-203.

40. Proctor R, Burns A, Powell HS, Tarrier N, Faragher B, Richardson G, Davies L, South B: Behavioural management in nursing and residential homes: a randomised controlled trial. Lancet 1999, 354(9172):26-29.

41. McCallion P, Toseland RW, Freeman K: An evaluation of a family visit education program. J Am Geriatr Soc 1999, 47(2):203-214.

42. Magai $C$, Cohen $\mathrm{Cl}$, Gomberg D: Impact of Training Dementia Caregivers in Sensitivity to Nonverbal Emotion Signals. Int Psychogeriatr 2002, 14(01):25-38.

43. McCallion P, Toseland RW, Lacey D, Banks S: Educating Nursing Assistants to Communicate More Effectively With Nursing Home Residents With Dementia. Gerontologist 1999, 39(5):546-558

44. Finnema E, Dröes R-M, Ettema T, Ooms M, Adèr H, Ribbe M, Tilburg Wv: The effect of integrated emotion-oriented care versus usual care on elderly persons with dementia in the nursing home and on nursing assistants: a randomized clinical trial. Int J Geriatr Psychiatry 2005, 20(4):330-343.

45. Hopman-Rock M, Staats PGM, Tak ECPM, Dröes R-M: The effects of a psychomotor activation programme for use in groups of cognitively impaired people in homes for the elderly. Int J Geriatr Psychiatry 1999, 14(8):633-642.

46. MacDonald ML, Settin JM: Reality orientation versus sheltered workshops as treatment for the institutionalized aging. J Gerontol 1978, 33(3):416-421.

47. Teri L, Huda P, Gibbons L, Young H, van Leynseele J: STAR: A DementiaSpecific Training Program for Staff in Assisted Living Residences. Gerontologist 2005, 45(5):686-693.

48. Opie J, Doyle C, O'Connor DW: Challenging behaviours in nursing home residents with dementia: a randomized controlled trial of multidisciplinary interventions. Int J Geriatr Psychiatry 2002, 17(1):6-13.

49. Cohen-Mansfield J, Libin A, Marx MS: Nonpharmacological treatment of agitation: a controlled trial of systematic individualized intervention. J Gerontol A Biol Sci Med Sci 2007, 62(8):908-916.

50. Lawton MP, Van Haitsma K, Klapper J, Kleban MH, Katz IR, Corn J: A Stimulation-Retreat Special Care Unit for Elders With Dementing Illness. Int Psychogeriatr 1998, 10(04):379-395

51. Brodaty H, Draper B, Millar J, Low L, Lie D, Sharah S, Paton H: Randomized controlled trial of different models of care for nursing home residents with dementia complicated by depression or psychosis. J Clin Psychiatry 2003, 64(1):63-72. 64(1):63-72 J.

52. Sloane PD, Hoeffer B, Mitchell CM, McKenzie DA, Barrick AL, Rader J, Stewart BJ, Talerico KA, Rasin JH, Zink RC: Effect of Person-Centered Showering and the Towel Bath on Bathing-Associated Aggression, Agitation, and Discomfort in Nursing Home Residents with Dementia: A Randomized, Controlled Trial. J Am Geriatr Soc 2004, 52(11):1795-1804.

53. Lin PW, Chan W, Ng BF, Lam LC: Efficacy of aromatherapy (Lavandula angustifolia) as an intervention for agitated behaviours in Chinese older persons with dementia: a cross-over randomized trial. Int J Geriatr Psychiatry 2007, 22(5):405-410.

54. Habraken H, Soenen K, Blondeel L, Van Elsen J, Bourda J, Coppens E, Willeput M: Gradual withdrawal from benzodiazepines in residents of homes for the elderly: experience and suggestions for future research. Eur J Clin Pharmacol 1997, 51(5):355-358.

55. Furniss L, Burns A, Craig SKL, Scobie S, Cooke J, Faragher B: Effects of a pharmacist's medication review in nursing homes: Randomised controlled trial. Br J Psychiatry 2000, 176(6):563-567.

56. Zermansky AG, Alldred DP, Petty DR, Raynor DK, Freemantle N, Eastaugh J, Bowie P: Clinical medication review by a pharmacist of elderly people living in care homes-randomised controlled trial. Age Ageing 2006, 35(6):586-591.

57. Ulfvarson J, Adami J, Ullman B, Wredling R, Reilly M, von Bahr C: Randomized controlled intervention in cardiovascular drug treatment in nursing homes. Pharmacoepidemiol Drug Saf 2003, 12(7):589-593.
58. Ulfvarson J, Adami J, Wredling R, Kjellman B, Reilly M, von Bahr C: Controlled withdrawal of selective serotonin reuptake inhibitor drugs in elderly patients in nursing homes with no indication of depression. Eur J Clin Pharmacol 2003, 59(10):735-740.

59. Bridges-Parlet S, Knopman D, Steffes S: Withdrawal of neuroleptic medications from institutionalized dementia patients: results of a double-blind, baseline-treatment-controlled pilot study. J Geriatr Psychiatry Neurol 1997, 10(3):119-126.

60. Paladino JA, Eubanks DA, Adelman MH, Schentag JJ: Once-Daily Cefepime Versus Ceftriaxone for Nursing Home Acquired Pneumonia. J Am Geriatr Soc 2007, 55(5):651-657.

61. Roberts MS, Stokes JA, King MA, Lynne TA, Purdie DM, Glasziou PP, Wilson DAJ, McCarthy ST, Brooks GE, Looze FJ: Outcomes of a randomized controlled trial of a clinical pharmacy intervention in 52 nursing homes. Br J Clin Pharmacol 2001, 51(3):257-265.

62. Crotty M, Whitehead C, Rowett D, Halbert J, Weller D, Finucane P, Esterman $A$ : An outreach intervention to implement evidence based practice in residential care: a randomized controlled trial [ISRCTN67855475]. BMC Health Serv Res 2004, 4(1):6.

63. Crotty M, Rowett D, Spurling L, Giles LC, Phillips PA: Does the addition of a pharmacist transition coordinator improve evidence-based medication management and health outcomes in older adults moving from the hospital to a long-term care facility? Results of a randomized, controlled trial. Am J Geriatr Pharmacother 2004, 2(4):257-264.

64. Loeb M, Brazil K, Lohfeld L, McGeer A, Simor A, Stevenson K, Zoutman D, Smith S, Liu X, Walter SD: Effect of a multifaceted intervention on number of antimicrobial prescriptions for suspected urinary tract infections in residents of nursing homes: cluster randomised controlled trial. BMJ 2005, 331(7518):669.

65. Schmidt I, Claesson CB, Westerholm B, Nilsson LG, Svarstad BL: The impact of regular multidisciplinary team interventions on psychotropic prescribing in Swedish nursing homes. J Am Geriatr Soc 1998, 46(1):77-82.

66. Cohen-Mansfield J, Lipson S, Werner P, Billig N, Taylor L, Woosley R: Withdrawal of Haloperidol, Thioridazine, and Lorazepam in the Nursing Home: A Controlled, Double-blind Study. Arch Intern Med 1999, 159(15):1733-1740.

67. Tse W, Frisina PG, Hälbig TD, Gracies J-M, Liang L, Tarshish C, Lesser G, Neufeld R, Koller WC, Libow LS: The Effects of Withdrawal of Dopaminergic Medication in Nursing Home Patients With Advanced Parkinsonism. J Am Med Dir Assoc 2008, 9(9):670-675.

68. Naughton BJ, Mylotte JM, Ramadan F, Karuza J, Priore RL: Antibiotic Use, Hospital Admissions, and Mortality Before and After Implementing Guidelines for Nursing Home Acquired Pneumonia. J Am Geriatr Soc 2001, 49(8):1020-1024.

69. Avorn J, Soumerai S, Everitt D, Ross-Degnan D, Beers M, Sherman D, SalemSchatz S, Fields D: A randomized trial of a program to reduce the use of psychoactive drugs in nursing homes. N Engl J Med 1992, 327(3):168-173.

70. Meador KG, Taylor JA, Thapa PB, Fought RL, Ray WA: Predictors of antipsychotic withdrawal or dose reduction in a randomized controlled trial of provider education. J Am Geriatr Soc 1997, 45(2):207-210.

71. Stein CM, Griffin MR, Taylor JA, Pichert JW, Brandt KD, Ray WA: Educational program for nursing home physicians and staff to reduce use of nonsteroidal anti-inflammatory drugs among nursing home residents: a randomized controlled trial. Med Care 2001, 39(5):436-445.

72. Schmidt I, Claesson C, Westerholm B, Nilsson L: Physician and staff assessments of drug interventions and outcomes in Swedish nursing homes. Ann Pharmacother 1998, 32(1):27-32

73. Fossey J, Ballard C, Juszczak E, James I, Alder N, Jacoby R, Howard R: Effect of enhanced psychosocial care on antipsychotic use in nursing home residents with severe dementia: cluster randomised trial. BMJ 2006, 332 (7544):756-761.

74. Remsburg RE, Luking AMY, Baran P, Radu C, Pineda D, Bennett RG, Tayback M: Impact of a Buffet-style Dining Program on Weight and Biochemical Indicators of Nutritional Status in Nursing Home Residents: A pilot study. J Am Diet Assoc 2001, 101(12):1460-1463.

75. Nijs KA, de Graaf C, Siebelink E, Blauw YH, Vanneste V, Kok FJ, van Staveren WA: Effect of Family-Style Meals on Energy Intake and Risk of Malnutrition in Dutch Nursing Home Residents: A Randomized Controlled Trial. J Gerontol A Biol Sci Med Sci 2006, 61(9):935-942.

76. Simmons SF, Keeler E, Zhuo X, Hickey KA, Sato H-w, Schnelle JF: Prevention of Unintentional Weight Loss in Nursing Home Residents: A Controlled Trial of Feeding Assistance. J Am Geriatr Soc 2008, 56(8):1466-1473. 
77. Essed NH, van Staveren WA, Kok FJ, de Graaf C: No effect of 16 weeks flavor enhancement on dietary intake and nutritional status of nursing home elderly. Appetite 2007, 48(1):29-36.

78. Castellanos VH, Marra MV, Johnson P. Enhancement of Select Foods at Breakfast and Lunch Increases Energy Intakes of Nursing Home Residents with Low Meal Intakes. J Am Diet Assoc 2009, 109(3):445-451.

79. Smoliner C, Norman K, Scheufele R, Hartig W, Pirlich M, Lochs H: Effects of food fortification on nutritional and functional status in frail elderly nursing home residents at risk of malnutrition. Nutrition 2008 , 24(11-12):1139-1144

80. Kwok T, Woo J, Kwan M: Does low lactose milk powder improve the nutritional intake and nutritional status of frail older Chinese people living in nursing homes? J Nutr Health Aging 2001, 5(1):17-21.

81. Splett PL, Roth-Yousey LL, Vogelzang JL: Medical nutrition therapy for the prevention and treatment of unintentional weight loss in residential healthcare facilities. J Am Diet Assoc 2003, 103(3):352-362.

82. van der Wielen RP, van Heereveld HA, de Groot CP, van Staveren WA: Nutritional status of elderly female nursing home residents; the effect of supplementation with a physiological dose of water-soluble vitamins. Eur J Clin Nutr 1995, 49(9):665-674.

83. Wouters-Wesseling W, Slump E, Kleijer CN, Groot LC, Staveren WA: Early nutritional supplementation immediately after diagnosis of infectious disease improves body weight in psychogeriatric nursing home residents. Aging Clin Exp Res 2006, 18:70-74. 2006, 18:70-74.

84. Wouters-Wesseling W, Wouters A, Kleijer C, Bindels J, de Groot C, van Staveren W: Study of the effect of a liquid nutrition supplement on the nutritional status of psycho-geriatric nursing home patients. Eur J Clin Nutr 2002, 56(3):245-251

85. Fiatarone Singh MA, Bernstein MA, Ryan AD, O'Neill EF, Clements KM, Evans WJ: The effect of oral nutritional supplements on habitual dietary quality and quantity in frail elders. J Nutr Health Aging 2000, 4(1):5-12.

86. Young KWH, Greenwood CE, van Reekum R, Binns MA: Providing Nutrition Supplements to Institutionalized Seniors with Probable Alzheimer's Disease Is Least Beneficial to Those with Low Body Weight Status. J Am Geriatr Soc 2004, 52(8):1305-1312.

87. Lauque S, Arnaud-Battandier F, Mansourian R, Guigoz Y, Paintin M, Nourhashemi F, Vellas B: Protein-energy oral supplementation in malnourished nursing-home residents. A controlled trial. Age Ageing 2000, 29(1):51-56

88. Beck AM, Damkjær K, Beyer N: Multifaceted nutritional intervention among nursing-home residents has a positive influence on nutrition and function. Nutrition 2008, 24(11-12):1073-1080.

89. Kikutani T, Enomoto R, Tamura F, Oyaizu K, Suzuki A, Inaba S: Effects of oral functional training for nutritional improvement in Japanese older people requiring long-term care. Gerodontology 2006, 23(2):93-98.

90. Yeh S, Wu SY, Levine DM, Parker TS, Olson JS, Stevens MR, Schuster MW Quality of life and stimulation of weight gain after treatment with megestrol acetate: correlation between cytokine levels and nutritional status, appetite in geriatric patients with wasting syndrome. J Nutr Health Aging 2000, 4(4):246-251.

91. Yeh SS, Wu SY, Lee TP, Olson JS, Stevens MR, Dixon T, Porcelli RJ, Schuster $\mathrm{MW}$ : Improvement in quality-of-life measures and stimulation of weight gain after treatment with megestrol acetate oral suspension in geriatric cachexia: results of a double-blind, placebo-controlled study. J Am Geriat Soc 2000, 48(5):485-492.

92. Yeh SS, WU SY, Levine DM, Parker TS, Olson IS, Stevens MR, Schuster MW: The Correlation of Cytokine Levels With Body Weight After Megestrol Acetate Treatment in Geriatric Patients. J Gerontol A Biol Sci Med Sci 2001 56(1):M48-M54

93. Liu BA, McGeer A, McArthur MA, Simor AE, Aghdassi E, Davis L, Allard JP: Effect of Multivitamin and Mineral Supplementation on Episodes of Infection in Nursing Home Residents: A Randomized, Placebo-Controlled Study. J Am Geriatr Soc 2007, 55(1):35-42.

94. Remarque EJ, van Beek WCA, Ligthart GJ, Borst RJA, Nagelkerken L, Palache AM, Sprenger MJW, Masurel N: Improvement of the immunoglobulin subclass response to influenza vaccine in elderly nursing-home residents by the use of high-dose vaccines. Vaccine 1993, 11(6):649-654

95. Palache AM, Beyer WEP, Sprenger MJW, Masurel N, de Jonge S, Vardy A, Charpentier B, Noury J, van Beek WCA, Borst RJA: Antibody response after influenza immunization with various vaccine doses: a double-blind, placebo-controlled, multi-centre, dose-response study in elderly nursing-home residents and young volunteers. Vaccine 1993, 11(1):3-9.
96. Gravenstein S, Drinka P, Duthie EH, Miller BA, Brown CS, Hensley M, Circo R, Langer E, Ershler WB: Efficacy of an influenza hemagglutinin-diphtheria toxoid conjugate vaccine in elderly nursing home subjects during an influenza outbreak. J Am Geriatr Soc 1994, 42(3):245-251.

97. Rudenko LG, Arden NH, Grigorieva E, Naychin A, Rekstin A, Klimov Al, Donina S, Desheva J, Holman RC, DeGuzman A: Immunogenicity and efficacy of Russian live attenuated and US inactivated influenza vaccines used alone and in combination in nursing home residents. Vaccine 2000, 19(2-3):308-318

98. Gaughran F, Walwyn R, Lambkin-Williams R, Whelan P, Chatterton K, Oxford J, Macdonald A: Flu: Effect of Vaccine in Elderly Care Home Residents: A Randomized Trial. J Am Geriatr Soc 2007, 55(12):1912-1920.

99. Gorse G, Otto E, Powers D, Chambers G, Eickhoff C, Newman F: Induction of mucosal antibodies by live attenuated and inactivated influenza virus vaccines in the chronically ill elderly. J Infect Dis 1996, 173(2):285-290.

100. Treanor JJ, Mattison HR, Dumyati G, Yinnon A, Erb S, O'Brien D, Dolin R, Betts RF: Protective efficacy of combined live intranasal and inactivated influenza A virus vaccines in the elderly. Ann Intern Med 1992, 117(8):625-633.

101. Miyagawa K, Hayashi Y, Kurihara S, Maeda A: Co-administration of I-cystine and I-theanine enhances efficacy of influenza vaccination in elderly persons: Nutritional status-dependent immunogenicity. Geriatr Gerontol Int 2008, 8(4):243-250.

102. Ben-Yehuda A, Joseph A, Barenholz Y, Zeira E, Even-Chen S, Louria-Hayon I, Babai I, Zakay-Rones Z, Greenbaum E, Galprin I: Immunogenicity and safety of a novel IL-2-supplemented liposomal influenza vaccine (INFLUSOMEVAC) in nursing-home residents. Vaccine 2003, 21(23):3169-3178.

103. Hayward AC, Harling R, Wetten S, Johnson AM, Munro S, Smedley J, Murad S, Watson JM: Effectiveness of an influenza vaccine programme for care home staff to prevent death, morbidity, and health service use among residents: cluster randomised controlled trial. BMJ 2006, 333(7581):1241.

104. Baldo V, Menegon T, Bonello C, Floreani A, Trivello R: Comparison of three different influenza vaccines in institutionalised elderly. Vaccine 2001, 19(25-26):3472-3475.

105. Pregliasco F, Mensi C, Serpilli W, Speccher L, Masella P, Belloni A: Immunogenicity and safety of three commercial influenza vaccines in institutionalized elderly. Aging (Milano) 2001, 13(1):38-43.

106. Glück R, Mischler R, Finkel B, Que JU, Cryz SJ, Scarpa B: Immunogenicity of new virosome influenza vaccine in elderly people. Lancet 1994, 344(8916):160-163.

107. Drinka PJ, Gravenstein S, Schilling M, Krause P, Miller BA, Shult P: Duration of Antiviral Prophylaxis During Nursing Home Outbreaks of Influenza A: A Comparison of 2 Protocols. Arch Intern Med 1998, 158(19):2155-2159.

108. Peters PH, Gravenstein S, Norwood P, Bock VD, Couter AV, Gibbens M, Planta T, Ward P: Long-Term Use of Oseltamivir for the Prophylaxis of Influenza in a Vaccinated Frail Older Population. J Am Geriatr Soc 2001, 49(8):1025-1031.

109. Monto A, Ohmit S, Hornbuckle K, Pearce C: Safety and efficacy of longterm use of rimantadine for prophylaxis of type $A$ influenza in nursing homes. Antimicrob Agents Chemother 1995, 39(10):2224-2228.

110. Gravenstein $S$, Drinka $P$, Osterweil $D$, Schilling $M$, Krause $P$, Elliott $M$, Shult $P$, Ambrozaitis A, Kandel R, Binder E: Inhaled Zanamivir Versus Rimantadine for the Control of Influenza in a Highly Vaccinated Long-term Care Population. J Am Med Dir Assoc 2005, 6(6):359-366.

111. Ambrozaitis A, Gravenstein S, van Essen GA, Rubinstein E, Balciuniene L, Stikleryte A, Crawford C, Elliott M, Shult P: Inhaled Zanamivir Versus Placebo for the Prevention of Influenza Outbreaks in an Unvaccinated Long-term Care Population. J Am Med Dir Assoc 2005, 6(6):367-374.

112. Schilling $M$, Povinelli $L$, Krause $P$, Gravenstein $M$, Ambrozaitis $A$, Jones $H H$, Drinka P, Shult P, Powers D, Gravenstein S: Efficacy of zanamivir for chemoprophylaxis of nursing home influenza outbreaks. Vaccine 1998, 16(18):1771-1774

113. Frey DE, Kelbley TJ, Durham L, James JS: Enhancing the self-esteem of selected male nursing home residents. Gerontologist 1992, 32(4):552-557.

114. Chiang KJ, Lu RB, Chu H, Chang YC, Chou KR: Evaluation of the effect of a life review group program on self-esteem and life satisfaction in the elderly. Int J Geriatr Psychiatry 2008, 23(1):7-10.

115. Lai CKY, Chi I, Kayser-Jones J: A randomized controlled trial of a specific reminiscence approach to promote the well-being of nursing home residents with dementia. Int Psychogeriatr 2004, 16(01):33-49. 
116. Rattenbury C, Stones MJ: A controlled evaluation of reminiscence and current topics discussion groups in a nursing home context. Gerontologist 1989, 29(6):768-771.

117. Owsley C, McGwin G Jr, Scilley K, Meek GC, Seker D, Dyer A: Effect of Refractive Error Correction on Health-Related Quality of Life and Depression in Older Nursing Home Residents. Arch Ophthalmol 2007, 125(11):1471-1477.

118. Yuen $\mathrm{H}$, Huang $\mathrm{P}$, Burik J, Smith T: Impact of participating in volunteer activities for residents living in long-term-care facilities. Am J Occup Ther 2008, 62(1):71-76.

119. Banks MR, Willoughby LM, Banks WA: Animal-Assisted Therapy and Loneliness in Nursing Homes: Use of Robotic versus Living Dogs. J Am Med Dir Assoc 2008, 9(3):173-177.

120. Lee LY, Lee DT, Woo J: Effect of Tai Chi on state self-esteem and healthrelated quality of life in older Chinese residential care home residents. $J$ Clin Nurs 2007, 16(8):1580-1582.

121. Corley MC, Ferriter J, Zeh J, Gifford C: Physiological and psychological effects of back rubs. Applied Nurse Res 1995, 8(1):39-42.

122. Schnelle JF, Kapur K, Alessi C, Osterweil D, Beck JG, Al-Samarrai NR, Ouslander JG: Does an Exercise and Incontinence Intervention Save Healthcare Costs in a Nursing Home Population? J Am Geriatr Soc 2003, 51(2):161-168.

123. Linn MW, Linn BS, Stein S, Stein EM: Effect of nursing home staff training on quality of patient survival. Int J Aging Hum Dev 1989, 28(4):305-315.

124. Kuske B, Luck T, Hanns S, Matschinger H, Angermeyer MC, Behrens J, RiedelHeller SG: Training in dementia care: a cluster-randomized controlled trial of a training program for nursing home staff in Germany. Int Psychogeriatr 2009, 21(02):295-308.

125. Robison J, Curry L, Gruman C, Porter M, Henderson CR Jr, Pillemer K: Partners in Caregiving in a Special Care Environment: Cooperative Communication Between Staff and Families on Dementia Units. Gerontologist 2007, 47(4):504-515

126. Schulz R: Effects of control and predictability on the physical and psychological well-being of the institutionalized aged. J Pers Soc Psychol 1976, 33(5):563-573.

127. Reinke BJ, Holmes DS, Denney NW: Influence of a "friendly visitor" program on the cognitive functioning and morale of elderly persons. Am J Community Psychol 1981, 9(4):491-504.

128. Kotynia-English R, McGowan H, Almeida OP: A randomized trial of early psychiatric intervention in residential care: impact on health outcomes. Int Psychogeriatr 2005, 17:475-485.

129. Nijs KA, de Graaf C, Kok FJ, van Staveren WA: Effect of family style mealtimes on quality of life, physical performance, and body weight of nursing home residents: cluster randomised controlled trial. BMJ 2006 332(7551):1180-1184.

130. Butts JB: Outcomes of Comfort Touch in Institutionalized Elderly Female Residents. Geriatr Nurs 2001, 22(4):180-184.

131. Sumaya IC, Rienzi BM, Deegan JF II, Moss DE: Bright Light Treatment Decreases Depression in Institutionalized Older Adults: A PlaceboControlled Crossover Study. J Gerontol A Biol Sci Med Sci 2001, 56(6): M356-M360.

132. Meeks S, Looney SW, Van Haitsma K, Teri L: BE-ACTIV: a staff-assisted behavioral intervention for depression in nursing homes. Gerontologist 2008, 48(1):105-114

133. Williams $C L$, Tappen RM: Exercise training for depressed older adults with Alzheimer's disease. Aging Ment Health 2008, 12(1):72-80.

134. Brittle N, Patel S, Wright C, Baral S, Versfeld P, Sackley C: An exploratory cluster randomized controlled trial of group exercise on mobility and depression in care home residents. Clin Rehabil 2009, 23(2):146-154.

135. Luijpen MW, Swaab DF, Sergeant JA, Scherder EJA: Effects of transcutaneous electrical nerve stimulation (TENS) on self-efficacy and mood in elderly with mild cognitive impairment. Neurorehabil Neural Repair 2004, 18(3):166-175.

136. Buettner LL, Fitzsimmons S: AD-venture program: Therapeutic biking for the treatment of depression in long-term care residents with dementia. Am J Alzheimers Dis Other Demen 2002, 17(2):121-127.

137. Fitzsimmons S: Easy rider wheelchair biking. A nursing-recreation therapy clinical trial for the treatment of depression. J Gerontol Nurs 2001, 27(5):14-23.

138. Krishnamurthy M, Telles S: Assessing depression following two ancient Indian interventions. J Gerontol Nurs 2007, 33(2):17-23.
139. der Lek RF Riemersma-van, Swaab DF, Twisk J, Hol EM, Hoogendijk WJ, Van Someren EJ: Effect of Bright Light and Melatonin on Cognitive and Noncognitive Function in Elderly Residents of Group Care Facilities: A Randomized Controlled Trial. JAMA 2008, 299(22):2642-2655.

140. Streim JE, Oslin DW, Katz IR, Smith BD, DiFilippo S, Cooper TB, Ten Have T: Drug treatment of depression in frail elderly nursing home residents. Am J Geriatr Psychiatry 2000, 8(2):150-159.

141. Burrows AB, Salzman C, Satlin A, Noble K, Pollock BG, Gersh T: A randomized, placebo-controlled trial of paroxetine in nursing home residents with non-major depression. Depress Anxiety 2002, 15 (3):102-110.

142. Magai C, Kennedy G, Cohen Cl, Gomberg D: A controlled clinical trial of sertraline in the treatment of depression in nursing home patients with late-stage Alzheimer's disease. Am J Geriatr Psychiatry 2000, 8(1):66-74.

143. Oslin D, Ten Have T, Streim J, Datto C, Weintraub D, DiFilippo S, Katz I: Probing the safety of medications in the frail elderly: evidence from a randomized clinical trial of sertraline and venlafaxine in depressed nursing home residents. J Clin Psychiatry 2003, 64(8):875-882.

144. Stinson CK, Kirk E: Structured reminiscence: an intervention to decrease depression and increase self-transcendence in older women. J Clin Nurs 2006, 15(2):208-218

145. Tsai Y-F, Wong TK, Tsai H-H, Ku Y-C: Self-worth therapy for depressive symptoms in older nursing home residents. $J$ Adv Nurs 2008, 64(5):488-494

146. McCurren C, Dowe D, Rattle D, Looney S: Depression among nursing home elders: Testing an intervention strategy. Applied Nurse Res 1999, 12(4):185-195

147. Rosen J, Rogers J, Marin R, Mulsant B, Shahar A, Reynolds C: Controlrelevant intervention in the treatment of minor and major depression in a long-term care facility. Am J Geriatr Psychiatry 1997, 5(3):247-257.

148. Tappen RM, Roach KE, Applegate EB, Stowell P: Effect of a combined walking and conversation intervention on functional mobility of nursing home residents with Alzheimer disease. Alzheimer Dis Assoc Disord 2000, 14(4):196-201

149. O'Hagan CM, Smith DM, Pileggi KL: Exercise classes in rest homes: effect on physical function. N Z Med J 1994, 107(971):39-40.

150. Schoenfelder DP, Rubenstein LM: An exercise program to improve fallrelated outcomes in elderly nursing home residents. Applied Nurse Res 2004, 17(1):21-31.

151. Lazowski D, Ecclestone N, Myers A, Paterson D, Tudor-Locke C, Fitzgerald C, Jones G, Shima N, Cunningham D: A randomized outcome evaluation of group exercise programs in long-term care institutions. J Gerontol A Biol Sci Med Sci 1999, 54(12):M621-M628.

152. Ouslander JG, Griffiths PC, McConnell E, Riolo L, Kutner M, Schnelle J: Functional Incidental Training: A Randomized, Controlled, Crossover Trial in Veterans Affairs Nursing Homes. J Am Geriatr Soc 2005, 53(7):1091-1100.

153. Donat $H$, Ozcan A: Comparison of the effectiveness of two programmes on older adults at risk of falling: unsupervised home exercise and supervised group exercise. Clin Rehabil 2007, 21(3):273-283.

154. Schnelle J, MacRae P, Giacobassi K, MacRae H, Simmons S, Ouslander J: Exercise with physically restrained nursing home residents: maximizing benefits of restraint reduction. J Am Geriatr Soc 1996, 44(5):507-512.

155. McMurdo MET, Rennie L: A Controlled Trial of Exercise by Residents of Old People's Homes. Age Ageing 1993, 22(1):11-15.

156. Baum E, Jarjoura D, Polen A, Faur D, Rutecki G: Effectiveness of a group exercise program in a long-term care facility: a randomized pilot trial. $J$ Am Med Dir Assoc 2003, 4(2):74-80.

157. Bruyere O, Wuidart MA, Di Palma E, Gourlay M, Ethgen O, Richy F, Reginster $J Y$ : Controlled whole body vibration to decrease fall risk and improve health-related quality of life of nursing home residents. Arch Phys Med Rehabil 2005, 86(2):303-307.

158. Kerse N, Peri K, Robinson E, Wilkinson T, von Randow M, Kiata L, et al: Does a functional activity programme improve function, quality of life, and falls for residents in long term care? Cluster randomised controlled trial. BMJ 2008, 337:a1445

159. Jensen J, Nyberg L, Rosendahl E, Gustafson Y, Lundin-Olsson L: Effects of a fall prevention program including exercise on mobility and falls in frail older people living in residential care facilities. Aging Clin Exp Res 2004, 16(4):283-292.

160. Sihvonen SE, Sipilä S, Era PA: Changes in Postural Balance in Frail Elderly Women during a 4-Week Visual Feedback Training: A Randomized Controlled Trial. Gerontology 2004, 50(2):87-95. 
161. Clark DC, Guest JL: The effectiveness of three different strengths of chlorhexidine mouthrinse. J Can Dent Assoc 1994, 60(8):711-714.

162. Willumsen T, Solemdal K, Wenaasen M, Øgaard B: Stannous fluoride in dentifrice: an effective anti-plaque agent in the elderly? Gerodontology 2007, 24(4):239-243.

163. Lo E, Luo Y, Tan H, Dyson J, Corbet E: ART and Conventional Root Restorations in Elders after 12 Months. J Dent Res 2006, 85(10):929-932.

164. Myoken $Y$, Yamane $Y$, Myoken $Y$, Nishida T: Plaque removal with an experimental chewable toothbrush and a control manual toothbrush in a care-dependent elderly population: a pilot study. J Clin Dent 2005, 16(3):83-86.

165. Simons D, Brailsford S, Kidd EAM, Beighton D: The effect of chlorhexidine acetate/xylitol chewing gum on the plaque and gingival indices of elderly occupants in residential homes. J Clin Periodontol 2001, 28(11):1010-1015.

166. Brailsford SR, Fiske J, Gilbert S, Clark D, Beighton D: The effects of the combination of chlorhexidine/thymol- and fluoride-containing varnishes on the severity of root caries lesions in frail institutionalised elderly people. J Dent 2002, 30(7-8):319-324.

167. Banting DW, Hill SA: Microwave disinfection of dentures for the treatment of oral candidiasis. Spec Care Dentist 2001, 21(1):4-8.

168. Frenkel H, Harvey I, Newcombe RG: Improving oral health in institutionalised elderly people by educating caregivers: a randomised controlled trial. Community Dent Oral Epidemiol 2001, 29(4):289-297.

169. Persson A, Lingström P, Bergdahl M, Claesson R, van Dijken JW: Buffering effect of a prophylactic gel on dental plaque in institutionalised elderly. Gerodontology 2007, 24(2):98-104

170. Ohno T, Uematsu H, Nozaki S, Sugimoto K: Improvement of taste sensitivity of the nursed elderly by oral care. J Med Dent Sci 2003, 50(1):101-107.

171. Day J, Martin MD, Chin M: Efficacy of a sonic toothbrush for plaque removal by caregivers in a special needs population. Spec Care Dentist 1998, 18(5):202-206.

172. Frenkel H, Harvey I, Needs K: Oral health care education and its effect on caregivers' knowledge and attitudes: a randomised controlled trial. Community Dent Oral Epidemiol 2002, 30(2):91.

173. Mohammad AR, Preshaw PM, Bradshaw MH, Hefti AF, Powala CV, Romanowicz M: Adjunctive subantimicrobial dose doxycycline in the management of institutionalised geriatric patients with chronic periodontitis. Gerodontology 2005, 22(1):37-43.

174. Becker C, Kron M, Lindemann U, Sturm E, Eichner B, Walter-Jung B, Nikolaus $\mathrm{T}$ : Effectiveness of a multifaceted intervention on falls in nursing home residents. J Am Geriatr Soc 2003, 51(3):306-313.

175. McMurdo MET, Millar AM, Daly F: A Randomized Controlled Trial of Fall Prevention Strategies in Old Peoples' Homes. Gerontology 2000, 46(2):83-87

176. Dyer CAE, Taylor GJ, Reed M, Dyer CA, Robertson DR, Harrington R: Falls prevention in residential care homes: a randomised controlled trial. Age Ageing 2004, 33(6):596-602

177. Neyens JCL, Dijcks BPJ, Twisk J, Schols JMGA, van Haastregt JCM, van den Heuvel WJA, de Witte LP: A multifactorial intervention for the prevention of falls in psychogeriatric nursing home patients, a randomised controlled trial (RCT). Age Ageing 2009, 38(2):194-199.

178. Kerse N, Butler M, Robinson E, Todd M: Fall Prevention in Residential Care: A Cluster, Randomized, Controlled Trial. J Am Geriatr Soc 2004, 52(4):524-531

179. Ray W, Taylor J, Meador K, Thapa P, Brown A, Kajihara H, Davis C, Gideon P, Griffin M: A randomized trial of a consultation service to reduce falls in nursing homes. JAMA 1997, 278(7):557-562.

180. Broe KE, Chen TC, Weinberg J, Bischoff-Ferrari HA, Holick MF, Kiel DP: A higher dose of vitamin $d$ reduces the risk of falls in nursing home residents: a randomized, multiple-dose study. J Am Geriatr Soc 2007, 55(2):234-239.

181. Flicker L, MacInnis RJ, Stein MS, Scherer SC, Mead KE, Nowson CA, Thomas J, Lowndes C, Hopper JL, Wark JD: Should Older People in Residential Care Receive Vitamin D to Prevent Falls? Results of a Randomized Trial. J Am Geriatr Soc 2005, 53(11):1881-1888.

182. Schoenfelder DP: A fall prevention program for elderly individuals. Exercise in long-term care settings. J Gerontol Nurs 2000, 26(3):43-51.

183. Rosendahl E, Gustafson Y, Nordin E, Lundin-Olsson L, Nyberg L: A randomized controlled trial of fall prevention by a high-intensity functional exercise program for older people living in residential care facilities. Aging Clin Exp Res 2008, 20(1):67-75.
184. Wagner LM, Capezuti E, Taylor JA, Sattin RW, Ouslander JG: Impact of a falls menu-driven incident-reporting system on documentation and quality improvement in nursing homes. Gerontologist 2005, 45(6):835-842.

185. Bouwen A, De Lepeleire J, Buntinx F: Rate of accidental falls in institutionalised older people with and without cognitive impairment halved as a result of a staff-oriented intervention. Age Ageing 2008, 37(3):306-310

186. Molloy DW, Guyatt GH, Russo R, Goeree R, O'Brien BJ, Bedard M, Willan A, Watson J, Patterson C, Harrison C: Systematic Implementation of an Advance Directive Program in Nursing Homes: A Randomized Controlled Trial. JAMA 2000, 283(11):1437-1444.

187. Casarett D, Karlawish J, Morales K, Crowley R, Mirsch T, Asch DA: Improving the Use of Hospice Services in Nursing Homes: A Randomized Controlled Trial. JAMA 2005, 294(2):211-217

188. Toye C, Percival P, Blackmore A: Satisfaction with nursing home care of a relative: does inviting greater input make a difference? Collegian 1996, 3(2):4-11.

189. Rantz MJ, Popejoy L, Petroski GF, Madsen RW, Mehr DR, Zwygart-Stauffacher M, Hicks LL, Grando V, Wipke-Tevis DD, Bostick J: Randomized Clinical Trial of a Quality Improvement Intervention in Nursing Homes. Gerontologist 2001, 41(4):525-538.

190. Mohide EA, Tugwell PX, Caulfield PA, Chambers LW, Dunnett CW, Baptiste S, Bayne JR, Patterson C, Rudnick KV, Pill M: A randomized trial of quality assurance in nursing homes. Med Care 1988, 26(6):554-565.

191. Hanson LC, Reynolds KS, Henderson M, Pickard CG: A Quality Improvement Intervention to Increase Palliative Care in Nursing Homes. J Palliat Med 2005, 8(3):576-584

192. Bravo G, Dubois MF, Roy PM: Using goal attainment scaling to improve the quality of long-term care: a group-randomized trial. Int J Qual Health Care 2005, 17(6):511-519.

193. Hodgson N, Freedman VA, Granger DA, Erno A: Biobehavioral Correlates of Relocation in the Frail Elderly: Salivary Cortisol, Affect, and Cognitive Function. J Am Geriatr Soc 2004, 52(11):1856-1862.

194. Hoeffer B, Talerico KA, Rasin J, Mitchell CM, Stewart BJ, McKenzie D, Barrick AL, Rader J, Sloane PD: Assisting cognitively impaired nursing home residents with bathing: effects of two bathing interventions on caregiving. Gerontologist 2006, 46(4):524-532.

195. Pillemer K, Suitor JJ, Henderson CR, Meador R, Schultz L, Robison J, Hegeman C: A Cooperative Communication Intervention for Nursing Home Staff and Family Members of Residents. Gerontologist 2003, 43(90002):96-106.

196. Linn MW, Linn BS, Stein S: Impact on nursing home staff of training about death and dying. JAMA 1983, 250(17):2332-2335.

197. Orrell M, Hancock G, Hoe J, Woods B, Livingston G, Challis D: A cluster randomised controlled trial to reduce the unmet needs of people with dementia living in residential care. Int J Geriatr Psychiatry 2007 22(11):1127-1134.

198. Hu TW, Kaltreider DL, Igou JF, Yu LC, Rohner TJ: Cost effectiveness of training incontinent elderly in nursing homes: a randomized clinical trial. Health Serv Res 1990, 25(3):455-477.

199. Aslan E, Komurcu N, Beji NK, Yalcin O: Bladder Training and Kegel Exercises for Women with Urinary Complaints Living in a Rest Home. Gerontology 2008, 54(4):224-231.

200. van Houten P, Achterberg W, Ribbe M: Urinary Incontinence in Disabled Elderly Women: A Randomized Clinical Trial on the Effect of Training Mobility and Toileting Skills to Achieve Independent Toileting. Gerontology 2007, 53(4):205-210.

201. Sackley CM, Rodriguez NA, van den Berg M, Badger F, Wright C, Besemer J, van Reeuwijk KT, van Wely L: A phase II exploratory cluster randomized controlled trial of a group mobility training and staff education intervention to promote urinary continence in UK care homes. Clin Rehabil 2008, 22(8):714-721.

202. Al-Samarrai NR, Uman GC, Al-Samarrai T, Alessi CA: Introducing a New Incontinence Management System for Nursing Home Residents. J Am Med Dir Assoc 2007, 8(4):253-261

203. Colling J, Ouslander J, Hadley B, Eisch J, Campbell E: The effects of patterned urge-response toileting (PURT) on urinary incontinence among nursing home residents. J Am Geriatr Soc 1992, 40(2):135-141.

204. Lackner TE, Wyman JF, McCarthy TC, Monigold M, Davey C: Randomized, Placebo-Controlled Trial of the Cognitive Effect, Safety, and Tolerability of Oral Extended-Release Oxybutynin in Cognitively Impaired Nursing 
Home Residents with Urge Urinary Incontinence. J Am Geriatr Soc 2008, 56(5):862-870.

205. Ouslander JG, Schapira M, Schnelle JF, Uman G, Fingold S, Tuico E, Nigam JG: Does Eradicating Bacteriuria Affect the Severity of Chronic Urinary Incontinence in Nursing Home Residents? Ann Intern Med 1995, 122(10):749-754

206. Ouslander JG, Schnelle JF, Uman G, Fingold S, Nigam JG, Tuico E, Jensen BB: Does oxybutynin add to the effectiveness of prompted voiding for urinary incontinence among nursing home residents? A placebocontrolled trial. J Am Geriatr Soc 1995, 43(6):610-617.

207. Ouslander JG, Greendale GA, Uman G, Lee C, Paul W, Schnelle J: Effects of Oral Estrogen and Progestin on the Lower Urinary Tract Among Female Nursing Home Residents. J Am Geriatr Soc 2001, 49(6):803-807.

208. Schnelle JF, Alessi CA, Simmons SF, Al-Samarrai NR, Beck JC, Ouslander JG: Translating Clinical Research into Practice: A Randomized Controlled Trial of Exercise and Incontinence Care with Nursing Home Residents. J Am Geriatr Soc 2002, 50(9):1476-1483.

209. Duffy LM, Cleary J, Ahern S, Kuskowski MA, West M, Wheeler L, Mortimer JA: Clean intermittent catheterization: safe, cost-effective bladder management for male residents of VA nursing homes. J Am Geriatr SoC 1995, 43(8):865-870

210. Stevens J, Kileen M: A randomised controlled trial testing the impact of exercise on cognitive symptoms and disability of residents with dementia. Contemp Nurse 2006, 21(1):32.

211. Stones MJ, Dawe D: Acute exercise facilitates semantically cued memory in nursing home residents. J Am Geriatr Soc 1993, 41(5):531-534.

212. Friedman R, Tappen RM: The effect of planned walking on communication in Alzheimer's disease. J Am Geriatr Soc 1991, 39(7):650-654.

213. Winblad B, Kilander L, Eriksson S, Minthon L, Båtsman S, Wetterholm A-L, Jansson-Blixt C, Haglund A: Donepezil in patients with severe Alzheimer's disease: double-blind, parallel-group, placebo-controlled study. Lancet 2006, 367(9516):1057-1065.

214. van Dongen $M$, van Rossum E, Kessels A, Sielhorst $H$, Knipschild P: Ginkgo for elderly people with dementia and age-associated memory impairment: a randomized clinical trial. J Clin Epidemiol 2003, 56(4):367-376.

215. Fernandez-Ballesteros R, Izal M, Diaz P, Gonzalez JL, Souto E: Training of conversational skills with institutionalized elderly: a preliminary study. Percept Mot Skills 1988, 66(3):923-926.

216. Meguro M, Kasai M, Akanuma K, Ishii H, Yamaguchi S, Meguro K Comprehensive approach of donepezil and psychosocial interventions on cognitive function and quality of life for Alzheimer's disease: the Osaki-Tajiri Project. Age Ageing 2008, 37(4):469-473.

217. Alessi CA, Martin JL, Webber AP, Kim EC, Harker JO, Josephson KR Randomized, controlled trial of a nonpharmacological intervention to improve abnormal sleep/wake patterns in nursing home residents. J Am Geriatr Soc 2005, 53(5):803-810.

218. Alessi CA, Schnelle JF, MacRae PG, Ouslander JG, al-Samarrai N, Simmons SF, Traub S: Does physical activity improve sleep in impaired nursing home residents? J Am Geriatr Soc 1995, 43(10):1098-1102.

219. Alessi CA, Yoon EJ, Schnelle JF, Al-Samarrai NR, Cruise PA: A randomized trial of a combined physical activity and environmental intervention in nursing home residents: do sleep and agitation improve? J Am Geriatr Soc 1999, 47(7):784-791.

220. Ancoli-Israel S, Martin JL, Kripke DF, Marler M, Klauber MR: Effect of Light Treatment on Sleep and Circadian Rhythms in Demented Nursing Home Patients. J Am Geriatr Soc 2002, 50(2):282-289.

221. Dowling GA, Hubbard EM, Mastick J, Luxenberg JS, Burr RL, Van Someren EJW: Effect of morning bright light treatment for rest and activity disruption in institutionalized patients with severe Alzheimer's disease. Int Psychogeriatr 2005, 17(02):221-236.

222. Dowling GA, Burr RL, Someren EJV, Hubbard EM, Luxenberg JS, Mastick J, Cooper BA: Melatonin and Bright-Light Treatment for Rest \& Activity Disruption in Institutionalized Patients with Alzheimer's Disease. J Am Geriatr Soc 2008, 56(2):239-246.

223. Martin JL, Marler MR, Harker JO, Josephson KR, Alessi CA: A multicomponent nonpharmacological intervention improves activity rhythms among nursing home residents with disrupted sleep/wake patterns. J Gerontol A Biol Sci Med Sci 2007, 62(1):67-72.

224. Meuleman JR, Nelson RC, Clark RL: Evaluation of temazepam and diphenhydramine as hypnotics in a nursing-home population. Drug Intell Clin Pharm 1987, 21(9):716-720.
225. O'Halloran PD, Cran GW, Beringer TRO, Kernohan G, O'Neill C, Orr J, Dunlop $L$, Murray LJ: A cluster randomised controlled trial to evaluate a policy of making hip protectors available to residents of nursing homes. Age Ageing 2004, 33(6):582-588.

226. O'Halloran PD, Murray LJ, Cran GW, Dunlop L, Kernohan G, Beringer TRO: The effect of type of hip protector and resident characteristics on adherence to use of hip protectors in nursing and residential homes-an exploratory study. Int J Nurs Stud 2005, 42(4):387-397.

227. Kiel DP, Magaziner J, Zimmerman S, Ball L, Barton BA, Brown KM, Stone JP, Dewkett D, Birge SJ: Efficacy of a hip protector to prevent hip fracture in nursing home residents: the HIP PRO randomized controlled trial. JAMA 2007, 298(4):413-422.

228. Cameron ID, Venman J, Kurrle SE, Lockwood K, Birks C, Cumming RG, Quine S, Bashford G: Hip protectors in aged-care facilities: a randomized trial of use by individual higher-risk residents. Age Ageing 2001, 30(6):477-481.

229. van Schoor NM, Smit JH, Twisk JWR, Bouter LM, Lips P: Prevention of hip fractures by external hip protectors: a randomized controlled trial. JAMA 2003, 289(15):1957-1962.

230. Bentzen H, Forsén L, Becker C, Bergland A: Uptake and adherence with soft- and hard-shelled hip protectors in Norwegian nursing homes: a cluster randomised trial. Osteoporos Int 2008, 19(1):101-111.

231. Meyer G, Warnke A, Bender R, Muhlhauser I: Effect on hip fractures of increased use of hip protectors in nursing homes: cluster randomised controlled trial. BMJ 2003, 326(7380):76

232. Meyer G, Wegscheider K, Kersten JF, Icks A, Mühlhauser I: Increased Use of Hip Protectors in Nursing Homes: Economic Analysis of a Cluster Randomized, Controlled Trial. J Am Geriatr Soc 2005, 53(12):2153-2158.

233. Langkamp-Henken B, Herrlinger-Garcia KA, Stechmiller JK, Nickerson-Troy JA, Lewis B, Moffatt L: Arginine Supplementation Is Well Tolerated but Does Not Enhance Mitogen-Induced Lymphocyte Proliferation in Elderly Nursing Home Residents with Pressure Ulcers. JPEN J Parenter Enteral Nutr 2000, 24(5):280-287.

234. Stechmiller JK, Langkamp-Henken B, Childress B, Herrlinger-Garcia KA, Hudgens J, Tian L, Percival SS, Steely R: Arginine Supplementation Does Not Enhance Serum Nitric Oxide Levels in Elderly Nursing Home Residents With Pressure Ulcers. Biol Res Nurs 2005, 6(4):289-299.

235. Murphy S, West KP, Greenough WB, Cherot E, Katz J, Clement L: Impact of Vitamin A Supplementation on the Incidence of Infection in Elderly Nursing-home Residents: A Randomized Controlled Trial. Age Ageing 1992, 21(6):435-439.

236. Monget AL, Richard MJ, Cournot MP, Arnaud J, Galan P, Preziosi P, Herbeth B, Favier A, Hercberg S: Effect of 6 month supplementation with different combinations of an association of antioxidant nutrients on biochemical parameters and markers of the antioxidant defence system in the elderly. The Geriatrie/Min.Vit.Aox Network. Eur J Clin Nutr 1996, 50(7):443-449.

237. Galan P, Preziosi P, Monget A, Richard M, Arnaud J, Lesourd B, Girodon F, Alferez $M$, Bourgeois $C$, Keller $\mathrm{H}$ : Effects of trace element and/or vitamin supplementation on vitamin and mineral status, free radical metabolism and immunological markers in elderly long termhospitalized subjects. Geriatric Network MIN. VIT. AOX. Int J Vitam Nutr Res 1997, 67(6):450-460.

238. Kapasi ZF, Ouslander JG, Schnelle JF, Kutner M, Fahey JL: Effects of an Exercise Intervention on Immunologic Parameters in Frail Elderly Nursing Home Residents. J Gerontol A Biol Sci Med Sci 2003, 58(7): M636-M643.

239. Langkamp-Henken B, Wood SM, Herlinger-Garcia KA, Thomas DJ, Stechmiller JK, Bender BS, Gardner EM, DeMichele SJ, Schaller JP, Murasko DM: Nutritional Formula Improved Immune Profiles of Seniors Living in Nursing Homes. J Am Geriatr Soc 2006, 54(12):1861-1870.

240. Ferrell BA, Osterweil D, Christenson P: A randomized trial of low-air-loss beds for treatment of pressure ulcers. JAMA 1993, 269(4):494-497.

241. Geyer MJ, Brienza DM, Karg P, Trefler E, Kelsey S: A randomized control trial to evaluate pressure-reducing seat cushions for elderly wheelchair users. Adv Skin Wound Care 2001, 14(3):120-129.

242. Lee SK, Posthauer ME, Dorner B, Redovian V, Maloney MJ: Pressure Ulcer Healing with a Concentrated, Fortified, Collagen Protein Hydrolysate Supplement: A Randomized Controlled Trial. Adv Skin Wound Care 2006, 19(2):92-96

243. Gerding G, Browning J: Oxyquinoline-containing ointment vs. standard therapy for stage I and stage II skin lesions. Dermatol Nurs 1992, 4(5):389-398. 
244. Duimel-Peeters IGP, Halfens R, Ambergen AW, Houwing RH, Berger MPF, Snoeckx LHEH: The effectiveness of massage with and without dimethyl sulfoxide in preventing pressure ulcers: A randomized, double-blind cross-over trial in patients prone to pressure ulcers. Int J Nurs Stud 2007 44(8):1285-1295

245. Riet Gt, Kessels AGH, Knipschild P: Randomised clinical trial of ultrasound treatment for pressure ulcers. BMJ 1995, 310(6986):1040-1041.

246. Vanderwee K, Grypdonck M, Bacquer DD, Defloor T: Effectiveness of turning with unequal time intervals on the incidence of pressure ulcer lesions. J Adv Nurs 2007, 57(1):59-68.

247. Greenspan SL, Schneider DL, McClung MR, Miller PD, Schnitzer TJ, Bonin R, Smith ME, DeLucca P, Gormley GJ, Melton ME: Alendronate Improves Bone Mineral Density in Elderly Women with Osteoporosis Residing in LongTerm Care Facilities: A Randomized, Double-Blind, Placebo-Controlled Trial. Ann Intern Med 2002, 136(10):742-746.

248. Chel V, Wijnhoven $H$, Smit J, Ooms M, Lips P: Efficacy of different doses and time intervals of oral vitamin $D$ supplementation with or without calcium in elderly nursing home residents. Osteoporos Int 2008, 19(5):663-671.

249. Agrawal S, Krueger DC, Engelke JA, Nest LJ, Krause PF, Drinka PJ, Binkley NC: Between-Meal Risedronate Does Not Alter Bone Turnover in Nursing Home Residents. J Am Geriatr Soc 2006, 54(5):790-795.

250. Law M, Withers $H$, Morris J, Anderson F: Vitamin D supplementation and the prevention of fractures and falls: results of a randomised trial in elderly people in residential accommodation. Age Ageing 2006, 35(5):482-486.

251. Lyons R, Johansen A, Brophy S, Newcombe R, Phillips C, Lervy B, Evans $R$, Wareham $K$, Stone M: Preventing fractures among older people living in institutional care: a pragmatic randomised double blind placebo controlled trial of vitamin D supplementation. Osteoporos Int 2007, 18(6):811-818

252. Cox H, Puffer S, Morton V, Cooper C, Hodson J, Masud T, Oliver D, Preedy D, Selby $\mathrm{P}$, Stone M: Educating nursing home staff on fracture prevention: a cluster randomised trial. Age Ageing 2008, 37(2):167-172.

253. Colón-Emeric CS, Lyles KW, House P, Levine DA, Schenck AP, Allison J, Gorospe J, Fermazin M, Oliver K, Curtis JR: Randomized Trial to Improve Fracture Prevention in Nursing Home Residents. Am J Med 2007, 120(10):886-892.

254. Kovach CR, Logan BR, Noonan PE, Schlidt AM, Smerz J, Simpson M, Wells T: Effects of the Serial Trial Intervention on Discomfort and Behavior of Nursing Home Residents With Dementia. Am J Alzheimers Dis Other Demen 2006, 21(3):147-155.

255. Chapman DG, Toseland RW: Effectiveness of advanced illness care teams for nursing home residents with dementia. Soc Work 2007, 52(4):321-329

256. Simmons S, Ferrell B, Schnelle J: Effects of a controlled exercise trial on pain in nursing home residents. Clin J Pain 2002, 18(6):380-385.

257. Hodgson NA, Andersen S: The clinical efficacy of reflexology in nursing home residents with dementia. J Altern Complement Med 2008, 14(3):269-275

258. Cook AJ: Cognitive-behavioral pain management for elderly nursing home residents. J Gerontol B Psychol Sci Soc Sci 1998, 53(1):51-59.

259. Buffum MD, Sands L, Miaskowski C, Brod M, Washburn A: A Clinical Trial of the Effectiveness of Regularly Scheduled Versus As-Needed Administration of Acetaminophen in the Management of Discomfort in Older Adults with Dementia. J Am Geriatr Soc 2004, 52(7):1093-1097.

260. Kovacs F, Abraira Vc, Santos S, Da-az E, Gestoso M, Muriel A, del Real MT Gil, Mufraggi N, Noguera J, Zamora J: A Comparison of Two Short Education Programs for Improving Low Back Pain-Related Disability in the Elderly: A Cluster Randomized Controlled Trial. Spine 2007, 32(10):1053-1059.

261. Avorn J, Langer E: Induced disability in nursing home patients: a controlled trial. J Am Geriatr Soc 1982, 30(6):397-400.

262. Przybylski BR, Dumont ED, Watkins ME, Warren SA, Beaulne AP, Lier DA: Outcomes of enhanced physical and occupational therapy service in a nursing home setting. Arch Phys Med Rehabil 1996, 77(6):554-561.

263. Tappen RM: The effect of skill training on functional abilities of nursing home residents with dementia. Res Nurs Health 1994, 17(3):159-165.

264. Sackley C, Wade DT, Mant D, Atkinson JC, Yudkin P, Cardoso K, Levin S, Lee $V B$, Reel K: Cluster randomized pilot controlled trial of an occupational therapy intervention for residents with stroke in UK care homes. Stroke 2006, 37(9):2336-2341.
265. Jablonski RA, Reed D, Maas ML: Care intervention for older adults with Alzheimer's disease and related dementias: effect of family involvement on cognitive and functional outcomes in nursing homes. $J$ Gerontol Nurs 2005, 31(6):38-48.

266. Mulrow CD, Gerety MB, Kanten D, Cornell JE, DeNino LA, Chiodo L, Aguilar C, O'Neil MB, Rosenberg J, Solis RM: A randomized trial of physical rehabilitation for very frail nursing home residents. JAMA 1994, 271(7):519-524.

267. Howard LV, West D, Ossip-Klein DJ: Chronic Constipation Management for Institutionalized Older Adults. Geriatr Nurs 2000, 21(2):78-82.

268. Pitkala K, Strandberg T, Finne Soveri U, Ouwehand A, Poussa T, Salminen S: Fermented cereal with specific bifidobacteria normalizes bowel movements in elderly nursing home residents. A randomized, controlled trial. J Nutr Health Aging 2007, 11(4):305-311.

269. Sturtzel B, Elmadfa I: Intervention with Dietary Fiber to Treat Constipation and Reduce Laxative Use in Residents of Nursing Homes. Ann Nutr Metab 2008, 52(Suppl. 1):54-56.

270. Bub S, Brinckmann J, Cicconetti G, Valentine B: Efficacy of an Herbal Dietary Supplement (Smooth Move) in the Management of Constipation in Nursing Home Residents: A Randomized, Double-Blind, PlaceboControlled Study. J Am Med Dir Assoc 2006, 7(9):556-561.

271. Chin A, Paw M, van Poppel M, van Mechelen W: Effects of resistance and functional-skills training on habitual activity and constipation among older adults living in long-term care facilities: a randomized controlled trial. BMC Geriatr 2006, 6(1):9.

272. Phillips SL, Branaman-Phillips J: The use of intramuscular cefoperazone versus intramuscular ceftriaxone in patients with nursing home-acquired pneumonia. J Am Geriatr Soc 1993, 41(10):1071-1074.

273. Orcel B, Delclaux B, Baud M, Derenne J: Oral immunization with bacterial extracts for protection against acute bronchitis in elderly institutionalized patients with chronic bronchitis. Eur Respir J 1994 7(3):446-452.

274. Valenzuela M, Altuzarra R, Trucco O, Villegas R, Inostroza J, Granata P Fleiderman J, Maggi L: Immunogenicity of a 23-valent pneumococcal polysaccharide vaccine in elderly residents of a long-term care facility. Brazilian J Infect Dis 2007, 11(3):322-326.

275. Meydani SN, Leka LS, Fine BC, Dallal GE, Keusch GT, Singh MF, Hamer DH: Vitamin $\mathrm{E}$ and respiratory tract infections in elderly nursing home residents: a randomized controlled trial. JAMA 2004, 292(7):828-836.

276. Loeb M, Carusone SC, Goeree R, Walter SD, Brazil K, Krueger P, Simor A, Moss L, Marrie T: Effect of a Clinical Pathway to Reduce Hospitalizations in Nursing Home Residents With Pneumonia: A Randomized Controlled Trial. JAMA 2006, 295(21):2503-2510.

277. Testad I, Aasland A, Aarsland D: The effect of staff training on the use of restraint in dementia: a single-blind randomised controlled trial. Int J Geriatr Psychiatry 2005, 20(6):587-590.

278. Huizing A, Hamers J, Gulpers M, Berger M: Short-term effects of an educational intervention on physical restraint use: a cluster randomized trial. BMC Geriatr 2006, 6(1):17.

279. Evans L, Strumpf N, Allen-Taylor S, Capezuti E, Maislin G, Jacobsen B: A clinical trial to reduce restraints in nursing homes. J Am Geriatr Soc 1997, 45(6):675-681.

280. Dawson M, Pilgrim A, Moonsawmy C, Moreland J: An evaluation of two bathing products in a chronic care setting. Geriatr Nurs 2001, 22(2):91-91

281. Sloane PD, Cohen LW, Williams CS, Munn J, Zimmerman S, Preisser JS, Sobsey MD, Wait DA: Effect of specialized bathing systems on resident cleanliness and water quality in nursing homes: a randomized controlled trial. J Water Health 2007, 5(2):283-294.

282. Bates-Jensen BM, Alessi CA, Al-Samarrai NR, Schnelle JF: The effects of an exercise and incontinence intervention on skin health outcomes in nursing home residents. J Am Geriatr Soc 2003, 51(3):348-355.

283. Himmelstein S, Clemens T, Rubin A, Lindsay R: Vitamin D supplementation in elderly nursing home residents increases $25(\mathrm{OH}) \mathrm{D}$ but not $1,25(\mathrm{OH})$ 2D. Am J Clin Nutr 1990, 52(4):701-706.

284. Lips P, Wiersinga A, van Ginkel FC, Jongen MJ, Netelenbos JC, Hackeng WH, Delmas PD, van der Vijgh WJ: The effect of vitamin D supplementation on vitamin D status and parathyroid function in elderly subjects. J Clin Endocrinol Metab 1988, 67(4):644-650.

285. Chel VGM, Ooms ME, Popp-Snijders C, Pavel S, Schothorst AA, Meulemans CCE, Lips P: Ultraviolet Irradiation Corrects Vitamin D Deficiency and Suppresses Secondary Hyperparathyroidism in the Elderly. J Bone Miner Res 1998, 13(8):1238-1242. 
286. Bond J, Gregson BA, Atkinson A: Measurement of Outcomes within a Multicentred Randomized Controlled Trial in the Evaluation of the Experimental NHS Nursing Homes. Age Ageing 1989, 18(5):292-302.

287. Cavalieri TA, Chopra A, Gray-Miceli D, Shreve S, Waxman H, Forman LJ: Geriatric assessment teams in nursing homes: do they work? J Am Osteopath Assoc 1993, 93(12):1269-1272.

288. Romieu I, Tellez-Rojo MM, Lazo M, Manzano-Patino A, Cortez-Lugo M, Julien P, Belanger MC, Hernandez-Avila M, Holguin F: Omega-3 Fatty Acid Prevents Heart Rate Variability Reductions Associated with Particulate Matter. Am J Respir Crit Care Med 2005, 172(12):1534-1540.

289. Ebihara S: Theophylline-Improved Swallowing Reflex in Elderly Nursing Home Patients. J Am Geriatr Soc 2004, 52(10):1787-1788.

290. Bautmans I, Demarteau J, Cruts B, Lemper JC, Mets T: Dysphagia in Elderly Nursing Home Residents with Severe Cognitive Impairment can be Attenuated by Cervical Spine Mobilization. J Rehabil Med 2008, 40:755-760

291. Yoder RM, Nelson DL, Smith DA: Added-purpose versus rote exercise in female nursing home residents. Am J Occup Ther 1989, 43(9):581-586.

292. Lee DT, Lee IF, Mackenzie AE, Ho RN: Effects of a Care Protocol on Care Outcomes in Older Nursing Home Patients with Chronic Obstructive Pulmonary Disease. J Am Geriatr Soc 2002, 50(5):870-876.

293. Watando A, Ebihara S, Ebihara T, Okazaki T, Takahashi H, Asada M, Sasaki H: Daily oral care and cough reflex sensitivity in elderly nursing home patients. Chest 2004, 126(4):1066-1070.

294. Simmons SF, Alessi C, Schnelle JF: An Intervention to Increase Fluid Intake in Nursing Home Residents: Prompting and Preference Compliance. J Am Geriatr Soc 2001, 49(7):926-933.

295. Eisses AMH, Kluiter H, Jongenelis K, Pot AM, Beekman ATF, Ormel J: Care staff training in detection of depression in residential homes for the elderly: Randomised trial. Br J Psychiatry 2005, 186(5):404-409.

296. Chassagne P, Jego A, Gloc P, Capet C, Trivalle C, Doucet J, Denis P, Bercoff $E$ : Does treatment of constipation improve faecal incontinence in institutionalized elderly patients? Age Ageing 2000, 29(2):159-164.

297. Teng X, Wong M, Zhang Y: The Effect of Music on Hypertensive Patients In Engineering in Medicine and Biology Society, 2007 EMBS 2007 29th Annual International Conference of the IEEE. Lyon, France:; 2007:4649-4651.

298. Berger RM, Rose SD: Interpersonal skill training with institutionalized elderly patients. J Gerontol 1977, 32(3):346-353.

299. Trick WE, Weinstein RA, DeMarais PL, Tomaska W, Nathan C, McAllister SK, Hageman JC, Rice TW, Westbrook G, Jarvis WR: Comparison of Routine Glove Use and Contact-Isolation Precautions to Prevent Transmission of Multidrug-Resistant Bacteria in a Long-Term Care Facility. J Am Geriatr Soc 2004, 52(12):2003-2009.

300. Nicolle LE, Mayhew WJ, Bryan L: Prospective randomized comparison of therapy and no therapy for asymptomatic bacteriuria in institutionalized elderly women. Am J Med 1987, 83(1):27-33.

doi:10.1186/1471-2318-12-31

Cite this article as: Gordon et al: A systematic mapping review of Randomized Controlled Trials (RCTs) in care homes. BMC Geriatrics 2012 12:31.

\section{Submit your next manuscript to BioMed Central and take full advantage of:}

- Convenient online submission

- Thorough peer review

- No space constraints or color figure charges

- Immediate publication on acceptance

- Inclusion in PubMed, CAS, Scopus and Google Scholar

- Research which is freely available for redistribution 